\title{
Tanggapan Mahasiswa Olahraga terhadap Pembelajaran Luring dan Daring
}

\author{
Suci Romadhoni Khasannah*, Siti Nurrochmah \\ Universitas Negeri Malang, Jl. Semarang No. 5 Malang, Jawa Timur, Indonesia \\ *Penulis korespondensi, Surel: suciromadhoni400@gmail.com
}

Paper received: 24-5-2021; revised: 14-6-2021; accepted: 21-6-2021

\begin{abstract}
The purpose of this study is to determine the responses of the class of 2018 PJKR FIK UM study program offering A, B, and C towards offline and online learning. The research method used is the descriptive quantitative. The research population is 206 students of the class of 2018 PJKR study program FIK UM. The research sample is 102 students of the class of 2018 PJKR FIK UM study program offering $\mathrm{A}, \mathrm{B}$, and $\mathrm{C}$. The analysis technique using descriptive quantitative statistics. The results of this study are 83 percent students agree with the theoretical course of offline learning, 84 percent students agree with the theoretical course of online learning, 91 percent students agree with the practical course of offline learning, and 89 percent students agree with the practical course of online learning. It can be concluded that the theoretical learning has fulfilled the principles of good learning.
\end{abstract}

Keywords: learning; offline; online; response

\begin{abstract}
Abstrak
Tujuan penelitian ini untuk mengetahui tanggapan mahasiswa angkatan 2018 Prodi PJKR FIK UM offering A, B, dan C terhadap pembelajaran luring dan daring. Metode penelitian yang digunakan yaitu deskriptif kuantitatif. Populasi penelitian ini berjumlah 206 mahasiswa Prodi PJKR-FIK-UM angkatan 2018. Sampel penelitian ini berjumlah 102 mahasiswa angkatan 2018 Prodi PJKR offering A, B dan C. Teknik analisis menggunakan statistika deskriptif kuantitatif. Hasil penelitian diperoleh 83 persen mahasiswa setuju dengan pembelajaran luring matakuliah teori, 84 persen mahasiswa setuju dengan pembelajaran daring matakuliah teori, 91 persen mahasiswa setuju dengan pembelajaran luring mata kuliah praktek, dan 89 persen mahasiswa setuju dengan pembelajaran daring mata kuliah praktek. Dapat disimpulkan bahwa pembelajaran luring dan daring telah memenuhi prinsip-prinsip belajar yang baik.
\end{abstract}

Kata kunci: pembelajaran; luring; daring; tanggapan

\section{Pendahuluan}

Seiring dengan perkembangan zaman dan berkembangnya cara berpikir manusia, IPTEK terus maju dan berkembang. Pendidikan adalah suatu aspek yang yang mendapat pengaruh besar dari kemajuan teknologi dan ilmu pengetahuan. Inovasi-inovasi yang berkembang sesuai IPTEK khususnya di bidang belajar dan pembelajaran sangat diperlukan pada di pendidikan. Pada tataran praktisnya, pendidikan merupakan aktivitas belajar yang didorong oleh proses interaksi atau suatu tindakan. Melalui proses belajar mengajar yang efektif maka tujuan pendidikan di Indonesia diharapkan akan terwujud, hal ini membuat membuat proses belajar mengajar menjadi faktor penting dan mempengaruhi hasil akhir dari lingkup pendidikan di Indonesia.

Hakekat dari belajar menurut Rahyubi (2014) yaitu pencapaian berbagai macam kompetensi, pengetahuan, keterampilan, dan sikap yang telah dilakukan dengan proses berlangsungnya hidup secara sadar atau tidak sadar yang harus dijalani semua manusia. 
Belajar dimaknai sebagai proses perubahan perilaku sebagai hasil interaksi individu dengan lingkungannya (Pane, 2017). Belajar adalah sebuah proses perubahan di dalam kepribadian manusia dan perubahan tersebut ditampilkan dalam bentuk peningkatan kualitas dan kuantitas tingkah laku seperti peningkatan kecakapan, pengetahuan, sikap, kebiasaan, pemahaman, ketrampilan, daya pikir, dan kemampuan-kemampuan yang lain (Ekayani, 2017). Proses belajar mengajar erat kaitannya dengan pembelajaran.

Dalam pembelajaran akan terjadi interaksi edukatif antara pendidik dan peserta didik yang baik akan menghasilkan proses pembelajaran yang efektif sebagaimana yang telah diharapkan (Hanafy, 2014). Pembelajaran adalah mengupayakan peserta didik untuk melakukan proses belajar dengan mengatur, mengorganisasi lingkungan di sekitar peserta didik (Pane, 2017). Pembelajaran memerlukan perencanaan untuk mencapai tujuan yang diharapkan oleh pendidik. Perencanaan pembelajaran meliputi penyusunan RPP, penyiapan media dan sumber belajar, perangkat penilaian pembelajaran, dan skenario pembelajaran (Lestari et al., 2020).

Model pembelajaran dibagi menjadi tiga yaitu pembelajaran luring, daring, dan campuran. Pada pembelajaran tatap muka pada lingkungan fisik terjadi komunikasi verbal spontan yang melibatkan mahasiswa (Tang, 2013). Pembelajaran luring merupakan pembelajaran yang mengandalkan kehadiran pengajar dan peserta didik dengan komunikasi secara langsung. Pada pembelajaran luring mewujudkan komunikasi langsung yang melibatkan mahasiswa pada lingkungan sekitar. Tang (2013) menyatakan pembelajaran daring adalah interaksi pembelajaran dengan menggunakan internet guna mempertemukan mahasiswa dan dosen. Konsep pembelajaran daring sama dengan e-learning. E-learning merupakan aplikasi internet yang dapat menghubungkan antara pendidik dan peserta didik dalam sebuah ruang belajar online (Suhana, 2020).

Kelebihan dari pembelajaran tatap muka yaitu ketersediaan mahasiswa untuk menghadiri pembelajaran tatap muka yang mempengaruhi psikologis, emosional saat melakukan pembelajaran. Sehingga pembelajaran menjadi lebih mudah dan materi mudah diserap karena bantuan dan penjelasan langsung dari dosen. Kelebihan dari pembelajaran online yaitu mahasiswa tidak harus menghadiri kelas, dengan menggunakan internet, pembelajaran bisa dilakukan kapan dan dimana saja. Pembelajaran menjadi lebih mudah, canggih, dan efisien.

Saat ini di seluruh dunia sedang terjadi sebuah pandemi yang berdampak cukup besar pada kehidupan manusia. Coronavirus Disease 2019 atau disebut dengan COVID - 19 telah ditetapkan oleh World Health Organization (WHO) sebagai sebuah ancaman pandemi. Pengertian pandemi menurut Kamus Besar Bahasa Indonesia (KBBI) merupakan wabah yang berjangkit secara menyeluruh pada geografi yang luas atau terjadi di mana-mana. Seiring dengan adanya virus covid-19 yang semakin merajalela, pemerintah membuat kebijakan physical distancing atau disebut juga dengan jaga jarak pada semua kegiatan termasuk pembelajaran. Penyelenggaraan pembelajaran secara daring atau online diajarkan pada perguruan tinggi (Firman \& Rahman, 2020). Sehingga pembelajaran sistem daring telah diterapkan di berbagai institusi pendidikan termasuk Universitas Negeri Malang pada Prodi PJKR-FIK

Pada Prodi PJKR-FIK-UM mahasiswa harus menempuh mata kuliah teori dan mata kuliah praktek. Mata Kuliah teori merupakan pembelajaran yang menuntut mahasiswa untuk 
memahami dan menguasai pengetahuan atau teori-teori secara terbimbing, terprogram, dan mandiri. Untuk menciptakan guru pendidikan jasmani yang berkompeten maka mahasiswa harus menempuh mata kuliah teori UMKK belajar dan pembelajaran. Mata Kuliah praktek adalah kegiatan pembelajaran mata kuliah praktek dengan deprogram dan dibimbing serta mandiri untuk mempelajari suatu keterampilan. Mata Kuliah praktek meliputi atletik, senam, renang, bolabasket, bolavoli, sepakbola, dan lainnya. Mata Kuliah sepakbola merupakan mata kuliah yang wajib ditempuh bagi mahasiswa S1 PJKR-FIK-UM yang mempelajari tentang teknik dasar keterampilan dan perwasitan pada olahraga sepakbola.

Melalui penelitian terdahulu telah dilakukan oleh Sadikin \& Hamidah (2020) tentang Pembelajaran Daring Di Tengah Wabah Covid-19, Rodriquez (2020) tentang Blended Learning Mata Kuliah Sepakbola untuk Mahasiswa PJKR, Zhafira (2020) tentang Persepsi Mahasiswa Terhadap Perkuliahan Daring Sebagai Sarana Pembelajaran. Berdasarkan permasalahan tersebut, didukung dengan hasil studi pendahuluan serta beberapa penelitian terdahulu yang terkait, maka peneliti melakukan penelitian yang berjudul "Tanggapan Mahasiswa Olahraga Terhadap Pembelajaran Luring dan Daring".

Tujuan penelitian ini untuk mengetahui tanggapan mahasiswa Prodi PJKR-FIK-UM offering A, B, dan C terhadap pembelajaran semester genap 2019/2020 yang meliputi pembelajaran luring pada matakuliah teori UMKK belajar dan pembelajaran, pembelajaran daring pada matakuliah teori UMKK belajar dan pembelajaran, pembelajaran luring pada matakuliah praktek sepakbola, dan pembelajaran daring pada matakuliah praktek sepakbola .

\section{Metode}

Penelitian menggunakan rancangan survei bentuk deskriptif kuantitatif. Adapun langkah-langkah penelitian kuantitatif disajikan pada gambar 1.

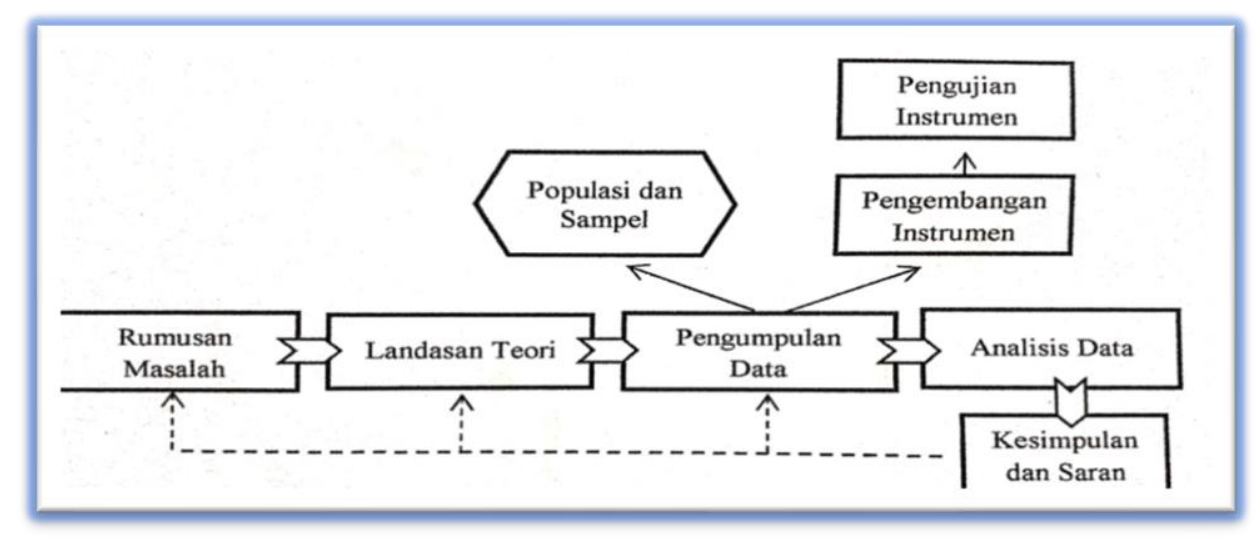

Gambar 1. Bagan Prosedur Penelitian Kuantitatif (Sugiyono, 2017)

Variabel yang diteliti berupa tanggapan mahasiswa angkatan 2018 Podi PJKR-FIK-UM offering A, B, dan C terhadap pembelajaran semester genap 2019/2020. Populasi penelitian ini berjumlah 206 mahasiswa Prodi PJKR-FIK-UM angkatan 2018. Pengambilan sampel menggunakan teknik proportionate simple random sampling dengan porsi 52\% Sampel penelitian ini berjumlah 102 mahasiswa angkatan 2018 Prodi PJKR offering A, B dan C. Pengumpulan data menggunakan instrumen non tes bentuk angket, dan data yang diperoleh 
melalui angket dianalisis menggunakan statistika deskriptif bentuk tendensi sentral yaitu frekuensi relatif.

\section{Hasil dan Pembahasan}

\subsection{Hasil}

Hasil analisis diperoleh pada pembelajaran luring mata kuliah teori Belajar dan Pembelajaran dapat dijelaskan bahwa alternative jawaban yang dipilih oleh responden pada pilihan jawaban ya dengan rata-rata 85 orang: $83 \%$ dan pilihan jawaban tidak rata-rata 17 orang: $17 \%$. Pada pembelajaran daring mata kuliah teori Belajar dan Pembelajaran diperoleh jawaban ya dengan rata-rata 85 orang: $84 \%$ dan pilihan jawaban tidak rata-rata 17 orang: $16 \%$.

Pada pembelajaran luring mata kuliah praktek Sepakbola diperoleh jawaban ya dengan rata-rata 92 orang: $90 \%$ dan jawaban tidak rata-rata 10 orang: $10 \%$. Pada pembelajaran daring mata kuliah praktek Sepakbola diperoleh jawaban ya dengan rata-rata 91 orang: 89\% dan jawaban tidak rata-rata 11 orang: $11 \%$.

Tabel 1. Data Rekapitulasi Indikator Pembelajaran Semester Genap 2019/2020

\begin{tabular}{|c|c|c|c|c|c|c|}
\hline \multirow{3}{*}{ Indikator } & \multicolumn{6}{|c|}{ Pilihan Jawaban } \\
\hline & \multicolumn{2}{|c|}{ Ya } & \multicolumn{2}{|c|}{ Tidak } & \multicolumn{2}{|c|}{ Total } \\
\hline & f & $\%$ & f & $\%$ & f & $\%$ \\
\hline Motivasi & 92 & 90 & 10 & 10 & 102 & 100 \\
\hline Perhatian & 91 & 89 & 11 & 11 & 102 & 100 \\
\hline Belajar mencakup semua aspek kehidupan & 88 & 86 & 14 & 14 & 102 & 100 \\
\hline Kesesuaian & 93 & 91 & 9 & 9 & 102 & 100 \\
\hline Variasi pengalaman belajar & 91 & 89 & 11 & 11 & 102 & 100 \\
\hline Mengaktifkan siswa & 97 & 95 & 5 & 5 & 102 & 100 \\
\hline Balikan & 84 & 82 & 18 & 18 & 102 & 100 \\
\hline Belajar membutuhkan orang lain & 96 & 94 & 6 & 6 & 102 & 100 \\
\hline $\begin{array}{l}\text { Belajar bevariasi dari yang sederhana sampai } \\
\text { dengan kompleks }\end{array}$ & 97 & 95 & 5 & 5 & 102 & 100 \\
\hline Perbedaan individual & 77 & 75 & 25 & 25 & 102 & 100 \\
\hline Belajar dimanapun dan kapanpun & 61 & 59 & 41 & 41 & 102 & 100 \\
\hline $\begin{array}{l}\text { Belajar didampingi pendidik atau tanpa } \\
\text { pendidik }\end{array}$ & 77 & 75 & 25 & 25 & 102 & 100 \\
\hline Memberikan kepuasan & 75 & 73 & 27 & 27 & 102 & 100 \\
\hline Jumlah & 1117 & 84 & 207 & 16 & 1326 & 100 \\
\hline
\end{tabular}

Pada pembelajaran semester genap menganut prinsip belajar motivasi dengan alternatif jawaban yang dipilih oleh responden pada pilihan jawaban ya dengan rata-rata 92 orang: $90 \%$ dan pilihan jawaban tidak rata-rata 10 orang: 10\%. Perhatian dengan alternatif jawaban yang dipilih oleh responden pada pilihan jawaban ya dengan rata-rata 91 orang: 89\%) dan pilihan jawaban tidak 11 orang: 11\%. Belajar mencakup semua aspek kehidupan dengan alternatif jawaban yang dipilih oleh responden pada pilihan jawaban ya dengan rata-rata 88 orang: $86 \%$ dan pilihan jawaban tidak 14 orang: 14\%. Kesesuaian dengan alternatif jawaban yang dipilih oleh responden pada pilihan jawaban ya dengan rata-rata 93 orang: $91 \%$ dan pilihan jawaban tidak 9 orang: $9 \%$. 
Variasi pengalaman belajar dengan alternatif jawaban yang dipilih oleh responden pada pilihan jawaban ya dengan rata-rata 91 orang: $89 \%$ dan pilihan jawaban tidak 11 orang: $11 \%$. Mengaktifkan siswa dengan alternatif jawaban yang dipilih oleh responden pada pilihan jawaban ya dengan rata-rata 97 orang: $95 \%$ dan pilihan jawaban tidak 5 orang: 5\%. Balikan dengan alternatif jawaban yang dipilih oleh responden pada pilihan jawaban ya dengan ratarata 84 orang: $82 \%$ dan pilihan jawaban tidak 18 orang: $18 \%$. Belajar memerlukan bantuan dan bimbingan orang lain dengan alternatif jawaban yang dipilih oleh responden pada pilihan jawaban ya dengan rata-rata 96 orang: $94 \%$ dan pilihan jawaban tidak 6 orang: $6 \%$.

Belajar bervariasi dari yang sederhana sampai dengan kompleks dengan alternatif jawaban yang dipilih oleh responden pada pilihan jawaban ya dengan rata-rata 97 orang: 95\% dan pilihan jawaban tidak 5 orang: 5\%. Perbedaan individual dengan alternatif jawaban yang dipilih oleh responden pada pilihan jawaban ya dengan rata-rata 77 orang: $75 \%$ dan pilihan jawaban tidak 25 orang: $25 \%$. Belajar dimanapun dan kapanpun dengan alternatif jawaban yang dipilih oleh responden pada pilihan jawaban ya dengan rata-rata 61 orang: 59\% dan pilihan jawaban tidak 41 orang: 41\%. Belajar berlangsung dengan pendidik atau tanpa pendidik dengan alternatif jawaban yang dipilih oleh responden pada pilihan jawaban ya dengan rata-rata 77 orang: $75 \%$ dan pilihan jawaban tidak 25 orang: $25 \%$. Memberikan kepuasan dengan alternatif jawaban yang dipilih oleh responden pada pilihan jawaban ya dengan rata-rata 75 orang: $73 \%$ dan pilihan jawaban tidak 27 orang: $27 \%$.

\subsection{Pembahasan}

Penelitian ini menggunakan instrumen non tes angket. Angket mempunyai keuntungan dan kekurangan. Keuntungan angket antara lain (1) responden dapat menjawab dengan bebas tanpa dipengaruhi oleh hubungan dengan peneliti atau penilai, dan waktu relatif lama sehingga objektivitas dapat terjamin, (2) informasi data terkumpul lebih mudah karena itemnya homogen, (3) dapat digunakan untuk mengumpulkan data dari jumlah responden yang besar yang dijadikan sampel. Kelemahannya adalah (1) ada kemungkinan angket diisi oleh orang lain, (2) hanya diperuntukkan bagi yang dapat melihat saja, (3) responden hanya menjawab berdasarkan jawaban yang ada (Arifin, 2016).

Sebelum disebarkan, angket terlebih dahulu diujicobakan untuk mendapatkan hasil yang baik. Berdasarkan hasil uji coba ditemukan koefisien validitas pada pembelajaran luring matakuliah teori belajar dan pembelajaran 0,565. Koefisien validitas pada pembelajaran daring mata kuliah teori belajar dan pembelajaran 0,618 . Koefisien validitas pada pembelajaran luring mata kuliah praktek sepakbola 0,651. Koefisien validitas pada pembelajaran daring mata kuliah praktek sepakbola 0,568. Sedangkan koefisien reliabilitas pada pembelajaran luring mata kuliah teori belajar dan pembelajaran 0,926. Koefisien reliabilitas pada pembelajaran daring mata kuliah teori belajar dan pembelajaran 0,944. Koefisien reliabilitas pada pembelajaran luring mata kuliah praktek sepakbola 0,956. Koefisien reliabilitas pada pembelajaran daring mata kuliah praktek sepakbola 0,952.

Dengan demikian 120 butir pertanyaan dapat dikatakan valid dan reliabel karena $\mathrm{r}$ hitung > r-tabel yaitu 0,444. Berarti instrumen angket dapat digunakan untuk memperoleh data tentang tanggapan mahasiswa angkatan 2018 Prodi PJKR-FIK-UM terhadap pembelajaran semester genap 2019/2020. Pada pembelajaran semester genap 2019/2020 terdapat 120 butir pernyataan yang disajikan. Pembelajaran luring pada matakuliah teori UMKK Belajar dan 
Pembelajaran 30 butir, pembelajaran daring pada matakuliah teori UMKK Belajar dan Pembelajaran 30 butir, pembelajaran luring pada matakuliah praktek Sepakbola 30 butir, dan pada pembelajaran daring pada matakuliah praktek Sepakbola 30 butir. Sebelum disebarkan, angket telah diujicobakan kepada 20 responden dan telah dinyatakan valid dan reliabel.

Berdasarkan hasil yang diperoleh, dapat disimpulkan bahwa pembelajaran semester genap 2019/2020 dapat dikatakan efektif karena telah menerapkan prinsip-prinsip belajar yang baik. Hasil survei menunjukkan bahwa pembelajaran luring efektif karena sebagian besar mahasiswa tidak terganggu dalam menghadiri kuliah tatap muka dan melihat kehadiran dalam pembelajaran tatap muka berpengaruh pada psikologis, emosional dan menyerap materi pembelajaran dan solusi atas masalah pembelajaran (Anggrawan, 2019). Interaksi yang bermakna dan nyata antara mahasiswa dengan mahasiswa dan antara mahasiswa dengan dosen pengajar yang tidak dapat digantikan atau dijumpai pada pembelajaran daring (Tang, 2013). Selain itu, penyampaian materi saat pembelajaran akan lebih mudah dipahami pada pembelajaran tatap muka (Sari, 2020:1365).

Model pembelajaran daring telah mampu meningkatkan penyerapan mahasiswa terhadap materi kuliah dibandingkan dengan hanya menggunakan model pembelajaran tatapmuka (Kuntarto, 2017). Ditemukan hasil penelitian yang unik dari penelitian Sadikin \& Hamidah (2020) yaitu mahasiswa merasa lebih nyaman dalam mengemukakan gagasan dan pertanyaan dalam pembelajaran daring karena mengikuti pembelajaran dari rumah membuat mereka tidak merasakan tekanan psikologis dari teman sebaya yang biasa mereka alami ketika mengikuti pembelajaran tatap muka. Namun, menurut Pangondian et al (2019) bahwa kendala pada pembelajaran daring yaitu tidak terpenuhinya kebutuhan internet hingga ke daerah pelosok karena modal utama dari pendidikan daring adalah layanan internet.

\section{Simpulan}

Berdasarkan hasil penelitian yang diperoleh dapat disimpulkan bahwa menurut tanggapan mahasiswa angkatan 2018 Prodi PJKR FIK UM Offering A, B, dan C, pembelajaran semester 2019/2020 yang terdiri dari pembelajaran luring pada matakuliah teori, pembelajaran daring pada matakuliah teori, pembelajaran luring pada matakuliah praktek dan pembelajaran daring pada matakuliah praktek dapat dikatakan efektif karena telah menerapkan prinsip-prinsip belajar yang baik. Diharapkan pendidik/dosen matakuliah teori dan praktek. Bagi mahasiswa dapat digunakan sebagai acuan untuk berbenah diri dalam mengelola waktu untuk belajar secara mandiri termasuk aktivitas lainya. Bagi lembaga sebagai bahan pertimbangan dan perbaikan dalam perkuliahan sehingga ada kemajuan dan perubahan dalam pelaksanaan pembelajaran mata kuliah teori dan praktek selanjutnya.

\section{Daftar Rujukan}

Anggrawan, A. (2019). Analisis Deskriptif Hasil Belajar Pembelajaran Tatap Muka dan Pembelajaran Online Menurut Gaya Belajar Mahasiswa. MATRIK: Jurnal Manajemen, Teknik Informatika Dan Rekayasa Komputer, 18(2), 339-346. https://doi.org/10.30812/matrik.v18i2.411

Arifin, Z. (2016). Evaluasi Pembelajaran (Prinsip, teknik, dan prosedur). Bandung: Remaja Rosdakarya.

Ekayani, P. (2017). (2017). Pentingnya Penggunaan Media Pembelajaran untuk Meningkatkan Prestasi Belajar Siswa. March. https://www.researchgate.net/publication/315105651

Firman, \& Rahman, S. R. (2020). Pembelajaran Online di Tengah Pandemi Covid-19 Firman1, Sari Rahayu Rahman1. Indonesian Journal of Educational Science (IJES), 2(2), 81-89.

Hanafy, M. S. (2014). Konsep Belajar dan Pembelajaran. Lentera Pendidikan: Jurnal Ilmu Tarbiyah Dan Keguruan. https://doi.org/10.24252/lp.2014v17n1a5 
Kuntarto, E. (2017). Keefektifan Model Pembelajaran Daring Dalam Perkuliahan Bahasa Indonesia di Perguruan tinggi. Journal Indonesian Language Education and Literature, 3(1), 53-65. http://www.syekhnurjati.ac.id/jurnal/index.php/jeill/\%0APEMBELAJARAN

Lestari, T. L., Winarno, M. E., \& ... (2020). Efektifitas Waktu Pelaksanaan Pembelajaran Pendidikan Jasmani, Olahraga dan Kesehatan di UPT Sekolah Dasar. Sport Science and Health, 2(9), 464-470. http://journal.um.ac.id/index.php/jptpp/article/view/13303

Pane, A. (2017). Belajar dan Pembelajaran Aprida Pane Muhammad Darwis Dasopang. Fitrah, 03(2), 333-352.

Pangondian R. Andrianto, R., Insap Santosa, P., \& Nugroho, E. (2019). Faktor - Faktor Yang Mempengaruhi Kesuksesan Pembelajaran Daring Dalam Revolusi Industri 4.0. Sainteks 2019, 56-60. https://seminarid.com/semnas-sainteks2019.html

Rahyubi, H. (2014). Teori-Teori Belajar Dan Aplikai Pembelajaran Motorik. Bandung: Nusa Media.

Rodriquez, E. I. S., Dwiyogo, W. D., \& Supriyadi. (2020). Blended Learning Matakuliah Sepakbola untuk Mahasiswa Pendidikan Jasmani Kesehatan dan Rekreasi. Jurnal Pendidikan: Teori, Penelitian, Dan Pengembagan, 5(2), 206-213.

Sadikin, A., \& Hamidah, A. (2020). Pembelajaran Daring di Tengah Wabah Covid-19. Biodik, 6(2), 109-119. https://doi.org/10.22437/bio.v6i2.9759

Sari, D. . (2020). Pembelajaran Tatap Muka dan Daring Terhadap Perkuliahan Mahasiswa/I Teknik Kimia. Prosiding Seminar Nasional Universitas Islam Syekh Yusuf, 1(1), 1364-1369.

Sugiyono. (2017). Metode Penelitian Bisnis (Pendekatan Kuantitatif, Kualitatif, Kombinasi dan R\&D). In Metodelogi Penelitian.

Suhana, C. (2020). Pengembangan Media Pembelajaran Berbasis Mobile Learning Untuk Aktifitas Kesegaran Jasmani Siswa kelas X Sekolah Menengah Kejuruhan. Sport Science and Health, 2(5), 272-278. http://journal2.um.ac.id/index.php/jfik/article/view/11828/5768

Tang, C. M. (2013). Readiness for Blended Learning: Understanding Attitude of University Students. International Journal of Cyber Society and Education, 6(2), 79-100. https://doi.org/10.7903/ijcse.1086

Zhafira, N. H., Ertika, Y., \& Chairiyaton. (2020). Persepsi Mahasiswa Terhadap Perkuliahan Daring Sebagai Sarana Pembelajaran Selama Masa Karantina Covid-19. Jurnal Bisnis dan Kajian Strategi Manajemen, 4, 37-45. 